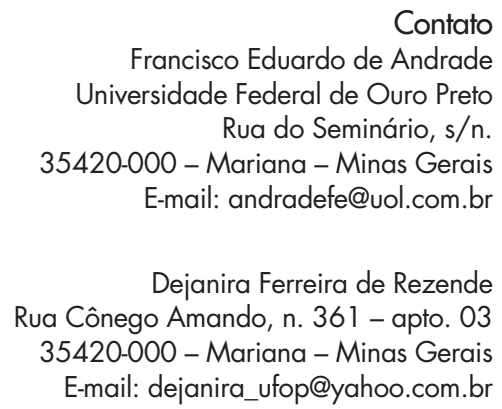

Contato

Francisco Eduardo de Andrade Universidade Federal de Ouro Preto Rua do Seminário, s/n. 35420-000 - Mariana - Minas Gerais E-mail: andradefe@uol.com.br

Dejanira Ferreira de Rezende Rua Cônego Amando, n. 361 - apto. 03 35420-000 - Mariana - Minas Gerais E-mail: dejanira_ufop@yahoo.com.br

\section{ESTILO DE MINERAR OURO NAS MINAS GERAIS ESCRAVISTAS, SÉCULO XVIII}

\section{Francisco Eduardo de Andrade}

Universidade Federal de Ouro Preto

\section{Dejanira Ferreira de Rezende}

Mestranda na Universidade Federal de Ouro Preto e bolsista Fundação de Amparo à Pesquisa do Estado de Minas Gerais

\title{
Resumo
}

A historiografia sobre as minas apega-se às determinações econômicas e técnicas da atividade mineradora, na América portuguesa. Buscamos, no entanto, relacionar técnica e direito (legal e costumeiro), salientando que este fundamenta a dinâmica ou evolução das práticas minerárias. Abordamos, ainda, as relações de trabalho constituídas nas unidades de extração aurífera: das diversas formas de associação às faisqueiras.

\section{Palavras-chave}

Estilo - relações de trabalho - mineração. 


\title{
GOLD MINING STYLE
} IN EIGHTEENTH CENTURY SLAVE OPERATED MINES

Contact

Francisco Eduardo de Andrade Universidade Federal de Ouro Preto Rua do Seminário, s/n. 35420-000 - Mariana - Minas Gerais E-mail: andradefe@uol.com.br

Dejanira Ferreira de Rezende Rua Cônego Amando, n. 361 - apto. 03 35420-000 - Mariana - Minas Gerais E-mail: dejanira_ufop@yahoo.com.br

\section{FranciscoEduardodeAndrade}

Universidade Federal de Ouro Preto

\section{Dejanira Ferreira de Rezende}

Master student of History - Universidade Federal de Ouro Preto - Fellowship of Fundação de

Amparo à Pesquisa do Estado de Minas Gerais

\begin{abstract}
The historiography of mines is closely related to economic and technical demands of the mining activity in Portuguese America. We seek to relate technique and Law (criminal and common) emphasizing that the latter substantiates the dynamics or evolution of the mining practices. We still cover labor relations incorporated in the gold extraction units, i.e., the diverse manners of association to gold lodes.
\end{abstract}

\section{Keywords}

Style - labor relations - mining. 


\section{Entre as técnicas e os direitos das minas}

A relação entre a extração avultada dos minerais preciosos e a configuração sistêmica da escravidão, engendrada na moderna colonização europeia, e portuguesa em especial, é considerada pela historiografia uma relação amplamente necessária. Neste sentido, a constituição da legitimidade das formas ou meios de trabalho, incluindo com isso as condições legais ou administrativas dos estilos de minerar, parece sempre vir a reboque das imposições econômicas ou técnicas.

Desde Roberto Simonsen e Caio Prado Júnior, houve uma tendência a conceber a evolução das fábricas minerárias nas minas do ouro e da produção do metal pressupondo-se, nas abordagens, o potencial natural dos depósitos auríferos e, sobretudo, a capacidade ou habilidade técnica dos mineradores/trabalhadores para extrair com proveito o mineral precioso. Assim, o auge e a crise das explorações resultaram da situação e do esgotamento das lavras ou, mais precisamente, do atraso tecnológico e das práticas exploradoras irracionais que então se observavam. ${ }^{1}$ Retomaram, com este ponto de vista, as interpretações das autoridades lusas ou luso-brasileiras e dos naturalistas estrangeiros do século XIX quando criticavam a decadência das capitanias/províncias dessas minas. O mineralogista Eschwege, com missão da corte portuguesa do Rio de Janeiro para estudar os meios de aumento da produção de ouro, concluiu que, nas Minas Gerais:

O mineiro brasileiro, que só pude conhecer bem depois de bastante trabalho, ajuíza em geral da utilidade de um trabalho ou de uma máquina, não pelo que ele ou ela pode realizar, mas só pelo que é capaz de produzir, sem levar em consideração as circunstâncias que constituem óbice ao fim colimado. Sua primeira pergunta, por exemplo, é: - Quanto ouro se tem conseguido com isso? Se a resposta não é inteiramente satisfatória, logo pontifica que o trabalho ou a máquina de nada vale, sem considerar o fato de o terreno poder produzir ouro ou não. ${ }^{2}$

Marcondes e Costa verificam, no entanto, que havia "racionalidade econômica" suficiente nas práticas minerárias. Aparentemente, as atitudes dos

\footnotetext{
${ }^{1}$ Cf. SIMONSEN, Roberto Cochrane. História econômica do Brasil: 1500-1820. $8^{\mathrm{a}}$ ed. São Paulo: Ed. Nacional, 1978, p. 291-295; PRADO JÚNIOR, Caio. Formação do Brasil contemporâneo. $20^{\mathrm{a}}$ ed. São Paulo: Brasiliense, 1987, p. 171.

2 ESCHWEGE, Wilhelm L. von. Pluto brasiliensis. v. 1. Tradução de Domício de Figueiredo Murta. Belo Horizonte/São Paulo: Itatiaia/ Edusp, 1979, p. 43.
} 
mineiros brasileiros seriam pouco lógicas e tudo consolidaria a desordem das aptidões, assumindo formas bastante ineficientes:

a inexistência de capitais e técnicas - para os trabalhos subterrâneos ou nas rochas mais resistentes -, a utensilagem empregada, a rotina dos processos, a ausência de conhecimento - ainda que rudimentar - da mineralogia e das técnicas de mineração aliadas à resistência dos mineiros em se associarem (o que tornaria possível a emergência de empreendimentos de maior vulto e eficiência) teriam levado, por um lado, a grandes perdas e, por outro, a abandonar-se precocemente a atividade mineratória. ${ }^{3}$

Os autores avaliam, no entanto, que essas conclusões não são consistentes, se realmente conferidas numa perspectiva histórica. Tais "perdas" resultavam da lógica político-econômica do colonialismo mercantilista (maximizar os ganhos em menor tempo possível), da organização regional do trabalho de extração, que se caracterizou pela dispersão competitiva dos "pequenos" exploradores ou mineradores e da disposição natural dos depósitos auríferos, de fácil extração (e pouco custo) por concentrarem-se junto à superfície nos sedimentos de aluviões. Devido a esse contexto, mesmo a crítica convencional ao costume de "abandono precoce" das lavras é "totalmente infundada", segundo os autores. Não seria precoce deixar um empreendimento de extração, cujos rendimentos caíam, por outro que prometesse maiores lucros. A conclusão é válida mesmo em se considerando, nestas "equações" ou cálculos, os custos da transferência de capital e trabalho e da nova montagem, somados também às perdas das inversões já realizadas com o "abandono" da velha lavra. Daí, dessa relação dinâmica entre campo de exploração ou ensaio de lavra nova e a organização efetivada da lavra antiga, pode-se compreender o processo de constituição das fronteiras econômicas e o seu ritmo ou evolução.

Na verdade, são práticas e decisões inscritas no sistema econômico de exploração colonial, como apontam Marcondes e Costa. "A dinâmica do 'sistema' conduziu mineradores e a própria Coroa". Mesmo que, em fase adiantada do século do ouro - digamos no período do surgimento das observações e propostas de cunho iluminista -, "estivessem presentes e disponíveis técnicas extrativas sofisticadas e conhecimentos mineralógicos apurados, seriam desprezados por sua desutilidade econômica, por não corresponderem ao quadro concreto em que se deram a ocupação, povoamento e exploração

\footnotetext{
MARCONDES, Renato Leite; COSTA, Iraci del Nero da. "Racionalidade econômica" e escravismo brasileiro: uma nota. Estudos de História. Franca, v. 9, n. 1, 2002, p. 253.
} 
das Gerais". ${ }^{4} \mathrm{O}$ sistema econômico, determinado sobretudo pela lógica escravista, não deixa de reger o processo histórico das minas.

O problema nessa análise, apesar de toda a sua força explicativa, é não considerar devidamente, como elementos que emprestam seus ritmos e conteúdos específicos às lógicas dos agenciamentos na mineração, os fatores culturais e político-jurídicos. Na realidade, as memórias científicas judiciosas, marcadas pelo discurso ilustrado, supunham que as mudanças técnicas na economia das minas auríferas deviam ser precedidas de intervenções na administração luso-brasileira e no direito minerário. Mas este era um assunto que exigia bastante cautela, pois envolvia os ganhos da Coroa e os preceitos que normalizavam as relações de poder no interior da América portuguesa. ${ }^{5}$ Essa força dos direitos régio e comum inscrevia-se nas leis das minas que codificavam os modos de apropriação e extração legítimas das lavras, mas não apresentavam disposições explícitas do arranjo, dos suportes técnicos envolvidos.

Nossa perspectiva, então, deve ser outra: não a que apresenta a tecnologia ou a lógica econômica simplesmente impondo-se aos tratos das minas com as suas mudanças, mas a que se propõe considerar as decisivas injunções da experiência dos direitos na constituição das práticas. Importa ainda considerar até uma inversão: os condicionantes técnicos ou as razões econômicas, que parecem presidir os modos de minerar ao longo do século XVIII, foram comumente reféns das práticas costumeiras dos trabalhadores (livres, forros e escravos) e da administração dos oficiais das minas.

Abordamos, assim, as práticas minerárias como efeito da inter-relação entre os direitos dos exploradores e as técnicas empregadas nessa ambiência da escravidão. ${ }^{6}$ Para isso, investigamos essas duas faces da prática de explo-

\footnotetext{
${ }^{4}$ Ibidem, p. 254.

5 Cf. LEME, Antonio Pires da Silva Pontes. Memória sobre a utilidade pública em se extrair o ouro das minas e os motivos dos poucos interesses que fazem os particulares, que mineram igualmente no Brasil. Revista do Arquivo Público Mineiro. Ouro Preto, v. 1, n. 3, jul.-set. 1896, p. 417-426 (doravante esta revista será referida como RAPM); Discurso político sobre as minas do ouro do Brasil por J. J. Feijó, 1797. História, Ciências, Saúde - Manguinhos. Rio de Janeiro, v. 11, n. 3, set.-dez. 2004, p. 739-748; Exposição do governador d. Rodrigo José de Meneses sobre o estado de decadência da Capitania de Minas Gerais e meios de remediá-lo [1780]. RAPM. Ouro Preto, v. 2, n. 2, abr.-jun. 1897, p. 311-325; Informação da Capitania de Minas Gerais dada em 1805 por Basílio Teixeira de Saavedra. RAPM. Ouro Preto, v. 2, n. 4, out.-dez. 1897, p. 673-683.

${ }^{6}$ Retomamos os supostos metodológicos de uma história cruzada, cf. ZIMMERMANN, Bénédicte; WERNER, Michael. Pensar a história cruzada: entre empiria e reflexividade. Textos de História. Brasília, v. 11, n. 1-2, 2003, p. 89-127. (Agradecemos a Mateus Pereira essa indicação). A proposição de constituição relacional do objeto surge, sinteticamente, em debate sobre o legado de Pierre Bourdieu, cf. CHARTIER, Roger. Pierre Bourdieu e a história. Debate com José Sérgio
} 
ração (ou de extração) do ouro, observando a sua combinação no território submetido à justiça da Vila do Carmo (ou cidade de Mariana, a partir de 1745) no século XVIII.

\section{Espacialidade dos tratos da mineração}

A história das formas ou dos recursos de exploração do ouro apreende os lugares de execução dos trabalhos, os cenários da lida. Os trabalhadores moviam-se entre os leitos dos ribeiros, os vales e os morros, buscando o mineral precioso conforme as oportunidades e os planos de ganhos. As mudanças de espaço obrigaram a um aporte técnico diferenciado e, principalmente, a relações de trabalho diversificadas, não redutíveis aos protagonistas convencionais - senhores e escravos -, e nem ao agenciamento do feitor ou de um administrador da lavra. ${ }^{7}$

Parece clássica, contudo, a imagem da mina explorada pelos negros escravos, submetidos ao estrito ordenamento de um senhor ou feitor. O engenheiro Miran Latif compôs até uma paisagem que apresenta junto da mina a casa-grande do proprietário, evocando aqui o microcosmo açucareiro da

Leite Lopes. In: BOURDIEU, Pierre; CHARTIER, Roger. O sociólogo e o historiador. Tradução de Guilherme João de Freitas Teixeira. Belo Horizonte: Autêntica Editora, 2011, p. 87-134.

7 Sobre a tecnologia empregada nas minas de ouro da América portuguesa, cf. ESCHEWEGE, Wilhelm L. von, op. cit., v. 1; HOLANDA, Sérgio Buarque de. A mineração: antecedentes luso-brasileiros. In: HOLANDA, Sérgio Buarque de (org.). História geral da civilização brasileira. A época colonial. $7^{\circ}$ edição. Rio de Janeiro: Bertrand Brasil, 1993, v. 2; HOLANDA, Sérgio Buarque de. Metais e pedras preciosas. Ibidem; RUSSELL-WOOD, Anthony J. R. Technology and society: The impact of gold mining on the institution of slavery in Portuguese America. The Journal of Economic History. Cambridge, v. 37, n. 1, mar. 1977, p. 59-83. Ainda tratando das técnicas da mineração na capitania de Minas Gerais, cf. FERRAND, Paul. O ouro em Minas Gerais. Tradução de Júlio Castanõn Guimarães. Belo Horizonte: Fundação João Pinheiro, 1998; GONÇALVES, Andréa Lisly. Escravidão, herança ibérica e africana e as técnicas de mineração em Minas Gerais no século XVIII. SEMINÁRIO SOBRE ECONOMIA MINEIRA, XI, Diamantina, 2004. Anais eletrônicos. Disponível em: http://econpapers.repec.org/bookchap/cdpdiam04/. Acesso em 16/05/2011; LUNA, Francisco Vidal. Mineração: métodos extrativos e legislação. Estudos Econômicos. São Paulo, v. 13, número especial, 1983, p. 845-859; PAIVA, Eduardo França. Bateias, carumbés, tabuleiros: mineração africana e mestiçagem no Novo Mundo. In: ANASTASIA, Carla Maria Junho; PAIVA, Eduardo França (orgs.). O trabalho mestiço, maneiras de pensar e formas de viver - séculos XVI a XIX. São Paulo/Belo Horizonte: Annablume/PPGH-UFMG, 2002, p. 187-207; REIS, Flavia Maria da Mata. Entre faisqueiras, catas e galerias: explorações do ouro, leis e cotidiano nas Minas do século XVIII (17021762). Dissertação de mestrado, História, Faculdade de Filosofia, Letras e Ciências Humanas, Universidade Federal de Minas Gerais, 2007; RENGER, Friedrich E. Direito mineral e mineração no Códice Costa Matoso (1752). Varia Historia. Belo Horizonte, n. 21, jul. 1999, p. 156-170. 
experiência de Gilberto Freyre. ${ }^{8}$ Mas Rugendas, que imaginou a extração aurífera em Ouro Preto do início do século XIX na situação de um novo descoberto, conferiu o burburinho dos livres pobres e dos escravos: "este método de explorar o ouro nos rios e suas margens é livre para qualquer pessoa e, por isto, sempre se veem muitos negros e outras pessoas da camada popular ocupados neste trabalho; a maioria gasta todo o lucro na venda próxima, em aguardente".?

As oportunidades e ocasiões, assim como o estilo, para explorar o mineral precioso surgem de modo variado, dependendo do lugar. A demarcação da data mineral (convencionalmente de 30 braças em quadra - de "largo" e de "comprido" -, conforme o artigo 50 do código das Minas de 1702) ${ }^{10}$ referiase à repartição de ribeiros "dos descobertos". Como é sabido, não se concedia automaticamente uma data inteira a todos os senhores, mesmo que tivessem a posse de escravos prevista no regimento minerário para a concessão desta (12 ou mais trabalhadores). Na prática, somente o descobridor, a Coroa, o superintendente e o guarda-mor das minas teriam o privilégio da concessão de data com o tamanho convencional. Os outros exploradores, mesmo que tivessem 12 ou mais escravos, precisavam aguardar a medição do ribeiro para saber se teriam direito a uma data inteira. Principalmente com o aumento expressivo de entrantes e exploradores das minas, a administração régia e local considerava, sobretudo para a divisão e demarcação das terras, o número dos interessados que legitimamente podiam compartilhar o descoberto. Propunha-se até, no Manual do Guarda-mor, que, sendo "pequeno o território à proporção dos concorrentes, o superintendente ordene que o guardamor faça a redução a palmos para a devida igualdade dos concorrentes"."1

\footnotetext{
${ }_{3}^{3}$ LATIF, Miran de Barros. As Minas Gerais. $3^{\text {a }}$ edição. Belo Horizonte: Agir, 1960. [Núcleo minerador].

9 RUGENDAS, Johann Moritz. Imagens e notas do Brasil. Revista do Patrimônio Histórico e Artístico Nacional. Rio de Janeiro, v. 13, 1956, p. 82-83.

10 "Braça", no dicionário de Bluteau, era a medida de "comprimento dos dous braços abertos, e estendidos, juntamente com a parte do corpo que está no meio deles, até à extremidade dos dedos do meio de cada mão". Cf. BLUTEAU, Rafael. Vocabulario portuguez e latino. Coimbra: Collegio das Artes da Companhia de Jesus, 1712, v. 2, p. 174. Modernamente, considera-se que a braça equivale a 2,2 m. Morais Silva, que havia reformado e ampliado o dicionário de Bluteau, apresentou ainda uma acepção de "quadra" no sentido que seria usual nas demarcações territoriais ("em quadra"): o lado de um quadrado. Cf. SILVA, Antônio Morais. Diccionario da lingua portugueza. Lisboa: Typographia Lacerdina, 1813. v. 2, p. 530.

${ }^{11}$ Manual do Guarda-mor, composto por Manuel José Pires da Silva Pontes. Revista do Arquivo Público Mineiro. Belo Horizonte, v. 7, 1902, p. 361 (atualizamos a grafia).
} 
Se houvesse a situação observada no regimento minerário de 1702 - descobrimento de ribeiro, número de entrantes e área compatíveis com as divisões de datas previstas -, os exploradores que possuíam menos de 12 escravos teriam direito a duas braças e meia "de comprido" por cada escravo possuído, e a 30 braças "de largo". Observa-se o fato de que, nesta valorização da largura proposta para a lavra, havia maior interesse em explorar os cascalhos do leito do ribeiro do que em buscar os depósitos nas elevações próximas. Contudo, era já tradicional o entendimento de que o aluvião rico seria proveniente das camadas mais profundas, conservadas nos altos montanhosos.

Assim, no regimento minerário (artigo 19), observa-se: nos ribeiros ricos, "que entra a sua riqueza muitas braças pela terra dentro, havendo pessoas que tenham ficado sem data pedindo-a nas sobre quadras, se repartirá na mesma forma". ${ }^{12}$ Contudo, não se repartirá as sobre quadras às pessoas que já tinham recebido o seu quinhão de terras no descoberto, pois o possuidor da data (com a forma de quadrado, ou em quadra) é quem teria direito a explorar sobre a quadra que demarcava a sua data ribeirinha. A expressão "sobre" torna-se elucidativa; Bluteau ensina, no seu dicionário, que se trata de "preposição local, que serve de mostrar a situação superior da coisa, que tem outra debaixo de si".13 $^{13}$

Essa possibilidade de avançar para as áreas elevadas, contíguas às lavras já apropriadas por descobridores e por mineradores ribeirinhos, aumentou a tensão entre os moradores e estimulou os conflitos que envolviam os administradores, os senhores e os lavradores, escravos e livres. No início do século XVIII, acirra-se a luta pela posse das áreas mais lucrativas, mostrando a insuficiência do regimento para constituir a legitimidade das pretensões de posse ou domínio.

O regimento, quando propunha que o minerador da data tivesse exclusividade de extração na área acima, negligenciava as consequências da desigualdade de posses dos senhores (escravos, ferramentas, gêneros para abastecimento) e as diferenças de rendimento das diversas lavras, conforme a localização e as características geofísicas do terreno. Alguns senhores, ou os trabalhadores pobres, que já tinham lavrado (ou tentado lavrar) as suas concessões, muitas vezes com resultados decepcionantes, certamente não supunham que fosse justo o direito de reservar para o dono da data uma

\footnotetext{
${ }^{12}$ Entre outras cópias, cf. Regimento dos Guardas-mores das Minas Gerais do ouro. Arquivo Público Mineiro, Seção colonial, Códice 02, f. 76v-82.

${ }^{13}$ BLUTEAU, Rafael, op. cit., v. 7, p. 174.
} 
sobre quadra. A situação devia parecer mais injusta, ou contrária ao direito comum ou aos costumes, se o minerador da data já tivesse lucrado com a demarcação original ou se fosse inconstante nas explorações (caso dos primeiros exploradores paulistas que transitavam entre as minas e o planalto de São Paulo), enquanto que outros labutavam ainda sem encontrar os ganhos que o negócio prometia.

Assim, sem o rompimento com o aparato jurídico primordial da administração das minas, tanto os administradores ou os juízes locais quanto as autoridades da Coroa portuguesa procuraram recompor o regimento minerário a partir das situações específicas de exploração. O que foi feito não simplesmente submetendo-se aos imperativos econômico-políticos ou às mudanças técnicas determinadas por maiores rendimentos, mas segundo a ótica de valores e direitos que também engendravam as situações e suas práticas.

A codificação mineira, conformando-se às experiências acumuladas por seus agentes, incorporou a administração pragmática dos conflitos advindos das apropriações das encostas dos morros e das extrações auríferas do subsolo. Tratou-se, a princípio, de adaptar os antigos (e consensuais) dispositivos às novas situações, para assim criar, efetivamente, outros mecanismos administrativos das explorações. Tais mecanismos surgiram, notadamente, na carta régia de 1720, sobre a concessão de águas para a mineração, que se articulou aos bandos da década de 1720 e do início da década de 1730, sobre as posses livres nos morros. Finalmente, em 1736, no governo de Gomes Freire de Andrada, previu-se a extração subterrânea, observada nas composições legais do bando de aditamento ao regimento antigo das lavras de aluvião. ${ }^{4}$ Neste último bando, reconhecia-se a variedade dos serviços e posses, a partir das duas situações básicas de repartição: "guardando-se o regimento sobre a medição e datas nos córregos e descobrimentos, nas mais terras, se guarde o costume estabelecido nas Minas, dando-se terras à proporção da pinta, fábricas e serviços necessários para minerá-las". ${ }^{15}$ Assim, nas Minas

\footnotetext{
${ }^{14}$ RENGER, Friedrich. E, op. cit., p. 159-162; ESCHEWEGE, Wilhelm L., op. cit., p. 103-112; ANDRADE, Francisco E. de. A invenção das Minas Gerais: empresas, descobrimentos e entradas nos sertões do ouro da América portuguesa. Belo Horizonte: Autêntica Editora; Editora PUC Minas, 2008, p. 301-303.

${ }^{15}$ Cf. FERREIRA, Francisco Ignácio. Repertorio juridico do mineiro. Consolidação alphabetica e chronologica. Rio de Janeiro: Typograhia Nacional, 1884, p. 80 (atualizamos a grafia). Em 1803, a lei distinguia nitidamente duas formas de apropriação das lavras (tentando agora rever a administração e as técnicas da área dos veios considerada mais rica): uma específica da concessão de datas, nas "grupiaras, tabuleiros, veios de águas, ribeirões, córregos, e em geral as formações de transporte ou aluvião, denominadas cascalho"; a outra forma referia-se aos "serviços [que compunham as "praças" da mineração] de morro, veeiros, betas, e quaisquer jazigos de ouro".
} 
Gerais, esse repertório jurídico dispôs os modos de exploração dos cascalhos e dos veios (ou betas) de ouro, influindo nas concepções (de descobrimento, de lavra, de posse, de serviço) que dimensionaram as mudanças técnicas.

Os direitos minerários na América portuguesa fundavam-se numa articulação casuísta entre os costumes locais e os direitos régio e comum. Nos costumes, sobretudo ainda no século XVIII, encontrava-se a legitimidade dos usos comuns e prescritos dos moradores coloniais, moldando-se às situações e às novidades. Em muitas ocasiões e temas, era por meio dos costumes, com sua gênese no mundo das práticas populares e da oralidade, que se chegava ao conhecimento e às interpretações do direito escrito. A rigor, qualquer rigidez na clivagem entre os costumes e o direito escrito ou erudito é um anacronismo; de fato, os costumes, conservados nos regimentos e nos bandos da legislação minerária da América portuguesa, tinham "força vinculante" e produziam o reconhecimento social das leis. ${ }^{16}$ Ensinava-se ao guarda-mor, em termos significativamente vagos, que, no desempenho da sua função, os "precedentes só valem sendo corolários de algum princípio. Usos e estilos legítimos devem ser guardados". ${ }^{17}$

A doutrina do direito português, de acordo com a retórica de um direito racional, admitia que o costume (consuetudo), sendo fundado ou inserido na ordem administrativa da justiça ("um uso introduzido por juiz"), isto é, se conformado a uma prática jurisdicional, estabelecia o que se denominava de estilo (stylus). O estilo, em um sentido estrito, poderia referir-se somente à

\footnotetext{
Arquivo Público Mineiro, Seção colonial, códice 292 [Alvará com força de lei, 23 de junho de 1803], p. 26 (atualizamos a grafia).

${ }^{16}$ Como foi examinado no direito indiano: "La oposición planteada entre uso [ou costume] y Derecho parece tener un cierto sabor modernizante. Mientras el Derecho son las reales ordenanzas, el derecho escrito, la práctica o uso parece como externos al propio Derecho. En esta instantánea literaria se refleja una mentalidad positivista en gérmen. Desde distintas áreas se va configurando una densa trama consuetudinaria, tejida de diversas experiencias, que cobra relieve propio para alcanzar una equiparación con la ley, sin que necesariamente aparezca enfrentado con ésta o en permanente conflicto de intereses". ANZOATÉGUI, Víctor Tau. El poder de la costumbre. Estudios sobre el Derecho consuetudinario en América hispana hasta la Emancipación, p. 36. Disponível em:http:// www.larramendi.es/i18n/catalogo_imagenes/grupo.cmd?path=1000174. Acesso em 13/02/2011.

${ }^{17}$ Revista do Arquivo Público Mineiro. Belo Horizonte, v. 7, 1902, p. 366. Não endossamos a conclusão de que os "costumes" tornaram-se pouco relevantes na solução jurídica dos conflitos ou litígios (especialmente na mineração), a partir da Lei da Boa Razão (1769). ANASTASIA, Carla M. J. A Lei da Boa Razão e o novo repertório da ação coletiva nas Minas setecentistas. Varia História. Belo Horizonte, n. 28, dez. 2002, p. 37-38. Observou-se que, de qualquer forma, "a realidade desse mundo jurídico não assimilado [pelo direito erudito] era de tal modo gritante" que se impunha "ao horizonte do jurista letrado" e às práticas do ofício. HESPANHA, António Manuel. Imbecillitas: as bem aventuranças da inferioridade nas sociedades de Antigo Regime. São Paulo: Annablume, 2010, p. 160, 174-175.
} 
atividade processual (ou ação administrativa), enquanto que, numa perspectiva mais abrangente, poderia incluir o conteúdo da decisão, aproximandose mais do significado proposto para o costume. ${ }^{18}$ Um jurista português, em 1715, com experiência da América, aponta o requisito do conceito jurídico: “Demais se confirma, que o estyllo para ser observado, deve ser geralmente practicado, e deduzido das razões do direyto e não contra elle [...] E assi o vi practicar, e practiquei sendo Ouvidor na Capitania de Itamaracá". ${ }^{19}$ Embora prevalecesse a perspectiva doutrinária de que a norma costumeira (que configurava "direito substantivo") pudesse ser contra a lei escrita ou régia, ao contrário do estilo, havia a noção de que as sentenças dos juízes manifestassem com mais legitimidade um costume expressivo da suposta vontade popular. ${ }^{20}$

As águas eram o recurso fundamental na tecnologia da extração aurífera nas minas. Esse líquido fazia-se necessário em qualquer método de exploração aurífera utilizado e em qualquer local (leito dos rios, tabuleiro, encostas das montanhas). Exigia-se, para a obtenção do metal - lavra e apuração -, o manejo das águas. Tratava-se, então, de ter acesso aos recursos hídricos ou à posse deles em contexto de avanço notável das explorações do subsolo, nas encostas dos morros, desde o final da primeira década do século XVIII. A posse das águas motivou várias contendas entre os mineradores e outros moradores das áreas urbanas ou as câmaras municipais que regulavam o abastecimento de água desses lugares, o qual era dificultado devido à grande parte dos mananciais próximos aos centros urbanos estarem concedidos a particulares, principalmente aos agentes da mineração. ${ }^{21}$ Notou-se que a construção de chafarizes nas vilas e arraiais mineradores aumentou à medida que a exploração aurífera decaía, já na segunda metade do século

\footnotetext{
${ }^{18}$ A discussão medieval e moderna sobre os limites entre os conceitos de costume e estilo é significativa. SILVA, Nuno J. Espinosa Gomes da. História do direito português. Fontes de direito. $4^{\mathrm{a}}$ edição. Lisboa: Fundação Calouste Gulbenkian, 2006, p. 376-388.

${ }^{19}$ Apud SILVA, Nuno J. Espinosa Gomes da, op. cit., p. 381.

${ }^{20}$ Pretendeu-se uma regra técnica para exame dos juristas: "dois actos, nomeadamente duas sentenças, no espaço de tempo de dez anos, são suficientes para induzir a existência de costume". Ibidem, p. 387 (em itálico no original).

${ }^{21}$ Denise Tedeschi, considerando as formas de apropriação das águas em Mariana no século XVIII, concluiu que a mineração aparecia como o principal motivo dos conflitos envolvendo água. TEDESCHI, Denise Maria Ribeiro. Águas urbanas: as formas de apropriação das águas em Mariana/ MG (1745-1798). Dissertação de mestrado, História, Instituto de Filosofia e Ciências Humanas/ Universidade Estadual de Campinas, 2011, p. 227.
} 
XVIII, pois as águas que antes eram preferencialmente empregadas nessa atividade puderam, então, ser utilizadas em proveito do "bem comum". ${ }^{22}$

Se, na prática, a posse das águas determinava o tamanho ou o potencial do serviço minerário, não se supunha mais uma medição prévia das terras minerais ("vagas") por quadras como nos descobrimentos. Daí os preceitos administrativos da repartição das águas, sob a égide do direito realengo das mercês, considerando os casos de petição: quando "vagas"; "excessivas"; "ociosas"; "desocupadas de noite e nos de dias de guarda"; "devolutas" (por causa de serviços abandonados); "sujeitas ao processo de devolução por se terem lavrado as terras correspondentes ou por terem morrido os escravos do provido"; "adventícias ou provenientes das chuvas"; e "subterrâneas ou descobertas a ponta de alavancas". ${ }^{23}$

Adensava a trama dos conflitos e ajustamentos entre os exploradores, poderosos e pobres o entendimento legal, que se torna dominante, de que os veios de ouro dos morros das Minas Gerais não eram de "descobertos", criando fortes obstáculos à aplicação do código minerário de 1702 e aos direitos de mercês. Contribuiu para o reconhecimento de que os morros significavam experiências distintas na mineração a criação das vilas em 1711 (Vila do Ribeirão de Nossa Senhora do Carmo, Vila Rica e Vila de Nossa Senhora da Conceição de Sabará), cujas implicações jurídicas e técnicas nas práticas de extração não devem ser negligenciadas. Geralmente havia justaposição entre as terras públicas dos rossios - as sesmarias demarcadas dos núcleos urbanos sob o domínio das câmaras - e as terras minerais exploradas e vagas, contribuindo para as noções de que os morros com seus recursos (madeiras, pastos, águas), englobados nos rossios, fossem para usos públicos. ${ }^{24}$

Os direitos sobre as águas por mercê (por meio da carta régia de 1720 e dos bandos dos governadores da capitania de Minas Gerais) coibiam o uso comum que permitiu, a princípio, que os livres pobres, forros e escravos jornaleiros ocupassem e explorassem com posses os morros. Mas não completamente, se lembrarmos que os bandos da década de 1720 especificavam

\footnotetext{
${ }^{22}$ FONSECA, Cláudia Damasceno. Arraiais e vilas d'el rei: espaço e poder nas Minas setecentistas. Tradução de Cláudia Damasceno Fonseca e Maria Juliana Gambogi Teixeira. Belo Horizonte: Editora UFMG, 2011, p. 525.

${ }^{25}$ Conforme os casos apresentados no Manual do Guarda-mor que, apesar de ser uma versão do século XIX (encaminhada por Afonso Pena aos editores da Revista do Arquivo Público Mineiro), baseia-se largamente na experiência e na legislação setecentistas. Revista do Arquivo Público Mineiro. Belo Horizonte, v. 7, 1902, p. 362-363.

${ }^{24}$ Cf. FONSECA, Cláudia Damasceno, op. cit., p. 463-484.
} 
que acima dos regos construídos para os serviços de águas e em terras vagas ou devolutas qualquer pessoa poderia fazer sua exploração. ${ }^{25}$

Nos morros, ou nos ribeiros, nas imediações dos núcleos urbanos e principalmente nas sedes dos termos, houve, com efeito, ajustamentos entre os senhores, livres pobres e escravos, proporcionando uma diversidade de arranjos na mineração. No manuscrito de meados do século XVIII, pretendendo relatar o "Modo e estilo que se tem observado e parece deve observar no uso de minerar nos morros e distrito de Vila Rica do Ouro Preto" e o "Modo e estilo de minerar que se tem observado nos morros da Passagem e de Santana, da cidade" de Mariana, havia uma identificação entre "terras comuns e realengas". Isso favoreceu as diversas formas de apropriação com obrigações mútuas, e uma rede de relações de trabalho. Os serviços de águas ("catas de talho aberto"), que garantiam as posses sustentadas por provisões dos administradores locais (e não por meio das cartas de datas), não podiam expulsar os faiscadores ou mineiros que, nos "buracos" acima destes maiores serviços, extraíam ouro. Se o dono do serviço com águas quisesse aprofundar a extração no subsolo e avançar sobre as áreas dos buracos, devia protestar contra qualquer impedimento para não ser obrigado a pagar pela apropriação que se seguisse. ${ }^{26}$

Os "pretos faiscadores", associando-se aos mineradores, também poderiam trabalhar nos "serviços de minas", buscando, em intricadas e rústicas galerias, o ouro das formações ou veios. Alguns senhores ainda, donos de minas, reservando o seu direito a uma parte do metal extraído, permitiam que os faiscadores explorassem as terras subterrâneas que separavam as minas e asseguravam o domínio particular dos veios. Ademais, outros pobres e faiscadores poderiam remexer as terras e areias depositadas nos córregos que recebiam os desmontes provenientes dos serviços minerais das elevações. Contudo, mesmo aqui, os senhores limitavam a ação ou a autonomia dos faiscadores, construindo tanques (mundéus) e canoas para conservar e lavar os desmontes, o que garantia as posses (e o direito à venda).

$\mathrm{O}$ estilo de minerar do morro de Passagem de Mariana (que pode se referir também ao antigo morro de Matacavalos), porque se descobriu "uma

\footnotetext{
${ }^{25}$ ESCHEWEGE, Wilhelm L., op. cit., p. 104, 108-109. ANDRADE, Francisco Eduardo de, op. cit., p. 301. ${ }^{26}$ FIGUEIREIDO, Luciano Raposo de Almeida; CAMPOS, Maria Verônica (orgs.). Códice Costa Matoso: coleção das notícias dos primeiros descobrimentos das minas na América que fez o doutor Caetano da Costa Matoso sendo ouvidor-geral das do Ouro Preto, de que tomou posse em fevereiro de 1749, e vários papéis. Belo Horizonte: Fundação João Pinheiro/ Centro de Estudos Históricos e Culturais, 1999, p. 766-769.
} 
só formação", não parece ter assumido a variação que se notava no morro de Vila Rica. As posses ocorriam por meio dos buracos nos primeiros tempos. A distribuição acirrada, que determinou quarenta palmos de distância entre os buracos, limitou as pretensões dos vizinhos, mas seguramente também obrigou os senhores e os trabalhadores a modos de exploração comum ou a acordos entre as partes. O reconhecimento legal das posses de minas e buracos deste morro não exigia investimento de monta, certamente devido à ocupação populacional e à relativa diversificação das atividades dos moradores que tendiam a identificar as posses com o lugar de moradia.

O manuscrito indica ainda que havia dois modos para se juntar águas, reagindo às posses e ao domínio dos mineradores estabelecidos: reunindo águas de chuva ou buscando "águas nativas". O primeiro, praticado no morro de Vila Rica, permitia aos pobres ou aos escravos jornaleiros, principalmente se trabalhassem conjuntamente, algum suprimento contínuo de águas. Era uma prática que dependia da construção de regos e reservatórios nos montes, acima dos serviços já instalados dos senhores. Nessas áreas, nenhuma pessoa poderia fazer canais que pudessem diminuir as águas de vertentes da chuva dos possuidores ou ferir os seus direitos adquiridos. O outro modo não favorecia os pobres ou a mobilidade dos escravos jornaleiros, pois exigia o acesso trabalhoso às nascentes de águas e à sua canalização, por meio de custosos regos e bicas, até as lavras. ${ }^{27}$ É certo que uma apropriação afetava a outra, principalmente quando alguns guardas-mores, enredados nos negócios das minas, concediam aos senhores (grandes mineradores) águas da chuva, o que prejudicava o suprimento dos outros lavradores, já que eram as águas pluviais que alimentavam muitos ribeiros. ${ }^{28}$

\section{Trabalhos nas lavras e nas faisqueiras}

Abordamos as práticas de extração do ouro na comarca de Vila Rica e, particularmente, no termo da Vila do Carmo (elevada à cidade de Mariana em 1745), investigando, no traçado conflituoso das ações cíveis e dos autos criminais setecentistas, e nos registros das lavras, os tratos dos exploradores

\footnotetext{
${ }^{27}$ Ibidem.

${ }^{28}$ FONSECA, Alberto de Freitas Castro; PRADO FILHO, José Francisco do. Um importante episódio na história da gestão dos recursos hídricos no Brasil: o controle da Coroa portuguesa sobre o uso da água nas minas de ouro coloniais. Revista Brasileira de Recursos Hídricos, v. 11, n. 3, jul.-set. 2006, p. 5-14.
} 
e seus estilos de trabalho. ${ }^{29}$ Os processos judiciais provinham da atividade jurisdicional da câmara municipal, por meio do juiz ordinário ou do juiz de fora (em Mariana, este magistrado foi atuante desde 1731). Entretanto, de acordo com as leis do Reino e a legislação das minas, o juizado camarário não detinha funções administrativas que lhe permitissem reger os conflitos da mineração. Previa-se que a administração das minas estivesse a cargo do guarda-mor e do superintendente (o ouvidor da comarca), sendo atribuição deste último, especialmente na primeira metade do século XVIII, solucionar os mais densos embates dos mineradores. As apelações e os agravos buscavam o tribunal da Relação com jurisdição nas Minas (o de Salvador até 1752 e, a partir desta data, o tribunal do Rio de Janeiro). ${ }^{30}$

Mesmo assim, na medida em que os direitos difusos dos moradores tinham nos juízes das câmaras uma descrição ou aceitação (escrita), repercutiam nesta instância as suas demandas e os confrontos mais violentos. ${ }^{31}$ Assim, os casos judiciais (tabela 1), na medida em que compunham os objetos da dissensão cotidiana, revelavam os tópicos das práticas minerárias, como os modos de trabalho, o uso dos instrumentos ou de engenhos (fábricas de minerar) e as técnicas empregadas. Por meio desta documentação foi possível apreender a diversificação das técnicas adaptadas a cada situação (nos ribeiros, tabuleiros, grupiaras), bem como as relações de trabalho dos exploradores locais, as quais envolviam senhores de escravos, homens livres ou libertos pobres e escravos.

\footnotetext{
${ }^{29}$ A pesquisa visou abranger todo o século XVIII, tendo como data limite o ano de 1808, porém coligimos somente os documentos relacionados diretamente às atividades minerárias, registrando as técnicas, as relações de trabalho e os conflitos dos agentes. Assim, a seleção documental definiu os períodos relativos às séries do Arquivo Histórico da Casa Setecentista de Mariana (AHCSM): processos criminais do $1^{\circ}$ e $2^{\circ}$ ofícios, 1735 a 1804; ações cíveis do $1^{\circ}$ e $2^{\circ}$ ofícios, 1710 a 1798; livros de Guardamoria, $2^{\circ}$ ofício, 1723 a 1788. Devido a essa organização das séries documentais, as tabelas que propusemos no artigo não apresentam a mesma periodização.

${ }^{30}$ Cf. ANDRADE, Francisco Eduardo de. A administração das minas do ouro e a periferia do poder. In: PAIVA, Eduardo França (org.). Brasil-Portugal: sociedades, culturas e formas de governo no mundo português. São Paulo: Annablume, 2006, p. 77-96.

${ }^{31}$ Percebe-se, no entanto, que, mesmo no âmbito administrativo, as câmaras conseguiam interferir nos assuntos da mineração do ouro ou de diamantes. Isso acontecia, por exemplo, quando as câmaras das Minas, exercendo suas atribuições jurisdicionais, regulavam ou fiscalizam vendas que se situavam nas áreas de mineração (notadamente dos morros) ou buscavam controlar os recursos hídricos urbanos.
} 


\section{Tabela 1: \\ Técnicas de extração do ouro nos casos judiciais, termo da Vila do Carmo/ Mariana, 1710-1804}

\begin{tabular}{|l|c|c|c|}
\hline \multicolumn{1}{|c|}{ Técnica } & Processo-crime & Ação cível & $\mathbf{0}$ \\
\hline Rosário/cercos (leito do rio) & 1 & 8 & 32,2 \\
\hline Catas (em geral no vale/tabuleiro) & 1 & 5 & 21,4 \\
\hline Talho aberto (grupiara/montanha) & - & 4 & 14,2 \\
\hline Faisqueira $^{*}$ & 3 & 6 & 32,2 \\
\hline Total $^{* *}$ & $\mathbf{5}$ & $\mathbf{2 3}$ & $\mathbf{1 0 0}$ \\
\hline
\end{tabular}

Fonte: AHCSM, Processos criminais e ações cíveis, $1^{\circ}$ e $2^{\circ}$ ofícios, 1710-1804.

* Termo genérico para tratar de uma situação de faiscação de ouro; usado para indicar os locais de pinta de ouro mais rarefeita, tanto os descobertos quanto os já lavrados.

** Refere-se somente aos casos com indicação da técnica utilizada, não incluindo todos os processos judiciais que apresentavam alguma relação com as práticas minerárias.

Nos vales, o escoamento da água dos serviços minerários poderia ser feito por meio de carumbés, carregados por escravos, ou com o uso dos rosários - engenhos de rodas d'água para drenagem das lavras. ${ }^{32}$ Para Vidal Luna, o uso desta última máquina teria sido pouco adotado nas Minas Gerais, prevalecendo o emprego dos carumbés. ${ }^{33}$ Porém, notamos um uso expressivo dos rosários (tabelas 1 e 2) entre os mineradores poderosos (aqueles usuários de capital e trabalho significativos) que encontravam apoio na instância judiciária da Vila do Carmo/Mariana ou que, detendo serviços de lavras, submetiam-se à administração local da guardamoria.

Observamos que o emprego desses engenhos parece acentuar-se desde o final dos anos 1730, nas buscas dos depósitos auríferos fundos situados nos vales ou nas encostas, por meio da abertura de catas. ${ }^{34}$ Até o início da década de 1730, as lavras comumente apresentavam os cercos (ou diques)

\footnotetext{
32 Os carumbés eram recipientes de madeira, de pouca profundidade e arredondados, semelhantes às bateias, porém com um diâmetro menor do que estas. ESCHWEGE, Wilhelm L. von, op. cit., p. 168. Estes eram utilizados também para carregar o material aurífero retirado das explorações.

33 LUNA, Francisco Vidal, op. cit., p. 852.

${ }^{34}$ As catas eram escavações feitas em forma de funil para a exploração do ouro dos veeiros. Era um método utilizado tanto nas margens dos rios quanto nas encostas mais altas. O rosário (ou nora) servia para drenar a água destas escavações.
} 
construídos nos leitos dos rios; mas, a partir da década seguinte, os serviços tendem à configuração técnica mais exigente, aumentando a extração aurífera por meio das catas e do método conhecido como talho aberto, praticado nos morros. Em alguns lugares do território de Mariana, notadamente nas paróquias do Sumidouro e de São Sebastião, usou-se com relativa frequência o talho aberto (tabela 2). ${ }^{35}$

Tabela 2:

Técnicas de extração: Guardamoria, termo da Vila do Carmo/Mariana, 1723-1788

\begin{tabular}{|l|c|c|}
\hline \multicolumn{1}{|c|}{ Técnica } & Números absolutos & \% \\
\hline Cercos & 7 & 7,2 \\
\hline Tanque p/ armazenar água & 7 & 7,2 \\
\hline Catas & 3 & 3,1 \\
\hline Talho aberto & 17 & 17,5 \\
\hline Rosário/roda de água & 18 & 18,6 \\
\hline Rego p/ conduzir água & 5 & 5,2 \\
\hline Serviço de minas & 4 & 4,1 \\
\hline Serviço de buracos & 3 & 3,1 \\
\hline Canoa & 1 & 1,0 \\
\hline Faisqueira & 1 & 1,0 \\
\hline Não consta & 31 & 32,0 \\
\hline Total* & $\mathbf{9 7}$ & $\mathbf{1 0 0}$ \\
\hline
\end{tabular}

Fonte: AHCSM, Livros de Guardamoria, $2^{\circ}$ ofício (1723-1788).

* O total não equivale ao número de registros de lavra dos livros, pois, em um mesmo registro, às vezes, houve referência a mais de uma técnica.

Azeredo Coutinho, no início do século XIX, argumentando que os mineradores não conheciam as técnicas avançadas de extração do ouro, considerava o rosário uma máquina muito precária. ${ }^{36}$ Mas sabemos que, no

${ }^{35}$ Cf. AHCSM, $2^{\circ}$ ofício, Livros de Guardamoria, 1723-1788. O método do talho aberto consistia em conduzir água até a jazida a ser explorada, onde algumas vezes era construído um reservatório superior. A água era então jorrada sobre a jazida e carregava a massa aurífera até o pé da montanha.

${ }^{36}$ COUTINHO, José Joaquim da Cunha de Azeredo. Discurso sobre o estado atual das Minas do Brasil [1804]. In: HOLANDA, Sérgio Buarque (org.). Obras econômicas de José Joaquim da Cunha de Azeredo Coutinho. São Paulo: Editora Nacional, 1966, p. 224. 
contexto da América portuguesa, o uso deste equipamento representou um avanço técnico, aumentando nitidamente a eficiência do trabalho na mineração - marca do compromisso duradouro com esta atividade. ${ }^{37}$

Estabelecer serviços de exploração mineral para chegar aos depósitos subterrâneos ou aos veios das encostas (por meio do método do talho aberto, dos buracos ou das "minas") exigia investimentos consideráveis e, por isso mesmo, tais serviços normalmente requeriam algum esforço conjunto dos mineradores, levando a formas mais estreitas de associação. Além das ferramentas e materiais, os serviços minerários de envergadura exigiam uma grande quantidade de mão-de-obra. Num serviço de cata que utilizava o engenho de drenagem (rosário), na paróquia de Sumidouro, foram alocados 130 trabaIhadores escravos, de acordo com um registro de lavra de um proprietário. ${ }^{38}$

As sociedades permitiam ampliar o potencial de trabalho das lavras, ou gerir, com flexibilidade, o contingente de escravos. Uma "sociedade" para um serviço de talho aberto, na paróquia de Furquim, empregou 150 escravos em 1753. ${ }^{39}$ Mas houveoutras sociedades notermo deMariana queutilizaram poucas dezenas de escravos. ${ }^{40} \mathrm{O}$ número variável de escravos utilizados nessas lavras e a natureza dos ajustes que implicavam numa associação dependiam evidentemente das condições técnicas e das injunções dos direitos dos exploradores.

É certo que os mineradores associavam-se quando a situação de exploração obrigava. A sociedade nas terras minerais (apropriação partilhada da data) e a associação em serviço mineral representam 28\% dos temas dos litígios das ações cíveis (tabela 3). Provavelmente, a frequência dessas sociedades, relacionadas à intensificação das práticas minerárias e à política fiscal, cresceu na segunda metade do século XVIII. ${ }^{41}$ Nos livros da administração local das minas, notam-se sociedades em 27,6\% das explorações registradas no período 1723-1748 e em 36,2\% dos registros do período 1752-1788, com uma grande concentração destas associações na década de 1750. Flávia Reis, por sua vez, verificou que 39,7\% dos mineradores da sua amostragem (inventá-

\footnotetext{
37 ESCHWEGE, Wilhelm L. Von, op. cit., p. 168; GONÇALVES, Andréa Lisly, op. cit., p. 8.

38 AHCSM, $2^{\circ}$ ofício, Livro de Guardamoria 8, 1761, f. 124.

39 AHCSM, $2^{\circ}$ ofício, Livro de Guardamoria 5, 1753, f. 55v.

40 AHCSM, $2^{\circ}$ ofício, Livro de Guardamoria 6, 1758, f. 220.

${ }^{41}$ A cobrança dos quintos através da casa de fundição (a partir de 1751) devia ser favorável, pelo menos inicialmente, ao plano técnico variável e à intensidade de trabalho das lavras (promovidos pela sociedade), pois era tributação que incidia sobre o ouro efetivamente extraído e não mais, como acontecia no sistema anterior da capitação, sobre o trabalhador (da mineração ou não), o que implicava na necessidade imediata de produção de excedente.
} 
REVISTA DE HISTÓRIA SÃO PAULO, N 168 , p. 382-413, JANEIRO / JUNHO 2013
Francisco Eduardo de Andrade e Dejanira F. de Rezende Estilo de minerar ouro nas Minas Gerais escravistas, século XVIII

rios pós-morte e testamentos das comarcas de Vila Rica e do Rio das Velhas) ligavam-se a alguma sociedade minerária. ${ }^{42}$

Tabela 3: Casos cíveis relacionados às práticas minerárias, 1710-1804

\begin{tabular}{|l|c|}
\hline \multicolumn{1}{|c|}{ Temas das ações cíveis } & Números \\
\hline Cobrança & 17 \\
\hline Posse de terras minerais & 8 \\
\hline Associação em serviço mineral & 7 \\
\hline Compra/venda de terras minerais & 7 \\
\hline Sociedade nas terras minerais & 7 \\
\hline Usos de água & 3 \\
\hline Furto & 1 \\
\hline Total & $\mathbf{5 0}$ \\
\hline
\end{tabular}

Fonte: AHCSM, Ações cíveis, $1^{\circ}$ e $2^{\circ}$ ofícios, 1710-1804.

Tabela 4: Organização das lavras do ouro, 1723-1788

\begin{tabular}{|c|c|c|c|c|}
\hline $\begin{array}{c}\text { Período/ } \\
\text { década }\end{array}$ & $\begin{array}{c}\text { Liberto } \\
\text { proprietário }\end{array}$ & $\begin{array}{c}\text { Livre } \\
\text { proprietário }\end{array}$ & Sociedade & Total \\
\hline $1723-1729$ & - & 2 & 2 & 4 \\
\hline $1730-1739$ & - & 7 & 1 & 8 \\
\hline $1740-1749$ & 4 & 8 & 5 & 17 \\
\hline $1750-1759$ & 2 & 19 & 14 & 35 \\
\hline $1760-1769$ & 1 & 9 & - & 10 \\
\hline $1770-1779$ & - & 4 & 3 & 7 \\
\hline $1780-1789$ & - & 2 & 4 & 6 \\
\hline Total & $\mathbf{7}$ & $\mathbf{5 1}$ & $\mathbf{2 9}$ & $\mathbf{8 7}$ \\
\hline
\end{tabular}

Fonte: AHCSM, Livros de Guardamoria, $2^{\circ}$ ofício (1723-1788).

\footnotetext{
$\overline{42}$ AHCSM, $2^{\circ}$ ofício, Livros de Guardamoria, 1723-1788; REIS, Flávia Maria da Mata, op. cit., p. 242.
} 
Os planos associativos dos mineradores, inscritos já nas determinações legais que regiam as minas do ouro desde 1702, não se enquadram na suposição mais convencional da historiografia. De acordo com Pandiá Calógeras, os esforços coletivos dos mineradores ao explorar o ouro de aluvião (o tipo que mais convinha aos seus interesses) não eram mais do que a soma de esforços individuais, sem relação e interdependência entre si. Os mineradores não se associavam na realização dos serviços, ainda que não pudessem executar as atividades com capitais individuais. Vivenciando uma economia muito competitiva, eles não mostravam um "espírito cooperativo" ${ }^{43}$ Friedrich Renger ainda segue a mesma interpretação, apontando que uma das principais causas da falta de tecnologia avançada na mineração em Minas Gerais colonial era "o sistema do minerador individual que trabalhava a sua mina com os seus escravos enquanto a mineração alemã já desde os tempos de Agricola tinha introduzido um sistema corporativista". ${ }^{44}$

Nossa perspectiva é bem distinta. Observamos que os administradores periféricos do Estado português e os mineradores propunham formas de cooperação variada que, às vezes, eram instituídas como forma de "sociedade". Os ajustes ou as composições entre eles eram flexíveis (ou instáveis) e seguiam a lógica dos direitos comum e costumeiro, além de atender aos planos de compartilhar as despesas e aumentar os lucros. Os mineradores e/ou faiscadores podiam unir-se tanto nas apropriações das terras minerais (sociedade nas terras minerais), quanto na execução de algum serviço específico de extração do metal (associação em serviço mineral).

Buscamos determinar as práticas constitutivas dessas associações em serviços minerais. Comumente, os mineradores empregavam escravos de outros proprietários (poderosos ou pobres) nas suas lavras, conforme os ajustes prévios entre os agentes, incluindo o pagamento de jornais aos trabalhadores ou o aluguel de escravos. ${ }^{45}$ Os senhores (com laços de parentesco e aliança) podiam

\footnotetext{
${ }^{43}$ CALÓGERAS, João Pandiá. As minas do Brasil e sua legislação. Rio de Janeiro: Imprensa Nacional, 1904, p. 133-134.

${ }^{44}$ RENGER, Friedrich E. Direito mineral e mineração no Códice Costa Matoso (1752). Varia História. Belo Horizonte, $n^{\circ}$ 21, jul. de 1999, p. 169. Georgius Agrícola foi um engenheiro alemão, autor de De Re Metallica, obra escrita em 1556 e que tratava de mineração e metalurgia.

${ }^{45} \mathrm{O}$ aluguel de escravos, a propósito, era prática usual na extração diamantina. Em 1752, José Luis Mayo moveu uma ação cível contra André Rodrigues Durão, cobrando-lhe os jornais de dois escravos seus que estiveram trabalhando algum tempo junto com os escravos do dito André Rodrigues. O trabalho era realizado não em lavras próprias deste último, mas de terceiros, e o jornal cobrado era de uma oitava de ouro semanal por cada cativo. AHCSM, $2^{\circ}$ ofício, Ação cível, Códice 386, Auto 10533, 1752.
} 
assumir maior risco, envolvendo-se diretamente com os serviços, sem que houvesse uma remuneração previamente estabelecida para os seus escravos, acordando em compartilhar posteriormente os rendimentos da extração.

Outra forma de associação tratava das terras, das lavras ou das faisqueiras (lugares de exploração que poderiam ser de benefício ou uso comum). Podiam consistir no que se conhecia como "lavrar de meias", o que ocorria quando um minerador disponibilizava uma quantidade de terras minerais para que os meeiros explorassem com autonomia. Ao final, o ouro seria repartido igualmente entre o dono da lavra e o meeiro. Especialmente os homens pobres (sem escravos ou donos de posses que não ultrapassavam cinco cativos), livres ou forros, quando pretendiam acesso às terras minerais particulares, podiam virar meeiros, concorrendo com o seu trabalho, ou o trabalho dos seus escravos, e com as próprias ferramentas. ${ }^{46}$

Havia ainda a prática de concessão de terras minerais "à terça", quando o possuidor das terras ou de lavras também permitia que mineradores ou faiscadores explorassem as suas datas ou posses. Estabelecia-se que uma das partes - o dono das terras auríferas ou o senhor que encaminhou cativos à exploração - ficaria com um terço do ouro extraído, ficando a outra parte com os dois terços restantes. A divisão, afinal, dependia de alguns condicionantes: a natureza da relação dos agentes e a posição política deles; o potencial de extração da terra (ou da data); a dimensão dos serviços requeridos; a organização dos trabalhos na lavra.

Gregório Ribeiro de Carvalho e André Barbosa Faria Maciel, mineradores da Vila do Carmo, confiaram nesse tipo de associação, o que implicou ainda em um esforço conjunto para os serviços da lavra. Mas logo houve um desentendimento entre ambos por falta de acordo sobre a divisão "à terça". Tanto Gregório, senhor que enviou escravos exploradores para o serviço, quanto André, o possuidor das lavras, pretendiam amealhar os dois terços dos rendimentos da extração de ouro. Na versão do procurador de Gregório, autor da ação judicial que relata a contenda, a associação teve um motivo específico:

Tendo o réu [André Barbosa] sentado uma roda para minerar nas suas terras (...) no ano próximo passado, e vendo que o tempo das águas se chegava sem que pudesse com a gente que trazia no serviço lavrar (...) toda aquela terra para que sentou a tal roda, para que a pudesse lavrar toda, em razão de não ficar algum resto que não merecia

${ }^{46}$ REIS, Flávia Maria da Mata, op. cit., p. 250. 
segundo serviço, convidou ao autor [Gregório Ribeiro] para que concorresse com alguns dos seus escravos para o mesmo serviço. ${ }^{47}$

Com efeito, parecia racional e legítima a pretensão do dono da lavra: buscar em tempo curto os maiores lucros possíveis. Assim, toda a extração devia ser executada até o início do período chuvoso, quando não seria mais possível empregar a técnica utilizada, a roda para drenagem da cata. No entanto, os agentes deviam atuar dentro dos limites costumeiros e respeitar os direitos minerários admitidos no âmbito da associação proposta.

André Barbosa ainda foi acusado de dispor dois escravos, da sua propriedade, para faiscar em serviço executado por todos que concorreram com cativos para a exploração. Gregório Ribeiro estranhou que, após a limpeza e o desmonte das catas, André tivesse metido os seus escravos "a faiscar no precioso da melhor parede ou pinta que se descobria". E isso ele não quis aceitar, argumentando que "qualquer pessoa que nesta terra dá terras minerais a terço, como o réu [André] deu ao autor [Gregório], não mete faiscadores na cata". ${ }^{48}$ Este último afirmou também que os negros faiscadores tiraram mais de 300 oitavas de ouro da mesma cata, valor que pretendia que fosse partilhado com ele. Enquanto isso, toda a lavra, onde trabalhavam mais de 40 escravos, teria rendido em torno de 707 oitavas de ouro.

Ainda que houvesse uma avaliação exagerada do ouro extraído pelos faiscadores, motivando os conflitos frequentes entre estes (escravos, forros, livres pobres) e os senhores das lavras, é bem provável que aqueles, aproveitando qualquer ocasião propícia, conseguissem amealhar (e desviar) quantidades consideráveis de ouro. Grande parte da rentabilidade da faiscação advinha destas práticas oportunistas, garantidas pela mobilidade e pela autonomia desses trabalhadores.

Esse relato indica que havia diferença entre os escravos de lavra e os escravos faiscadores. Os primeiros deviam atuar em um determinado local, conforme as suas posições no processo de trabalho. Nos tratos da cooperação entre Gregório e André, havia um papel a ser desempenhado por cada um, ou por sua "gente" (jornaleiros ou escravos) na lavra, e isso obrigava a alguma forma de demarcação, embora fosse esta pouca rígida. Os faiscadores, no entanto, integravam-se às lavras com relativa autonomia, manipulando o plano administrativo concebido pelos senhores.

\footnotetext{
47 AHCSM, $2^{\circ}$ ofício, Ação cível, Códice 400, Auto 11302, 1730.

48 Ibidem.
} 
A defesa de André assumiu a perspectiva de que o acordo estabelecido entre os contendores não configurava uma sociedade nos recursos minerários. Assim, alegou que:

É uso e costume nestas Minas todas as pessoas que (...) são senhores de serviços e deixam neles trabalhar outras pessoas a terça meter no serviço a trabalhar alguns escravos por onde lhe parece e outrossim nunca o réu foi sócio com o autor para efeito de que lhe dê partilha do que [extraíram] os dois escravos [faiscadores]. ${ }^{49}$

Gregório Ribeiro também era dono de lavras, embora tivesse empregado 35 escravos na cata de André Barbosa. Estes trabalharam ali durante um mês, dirigidos por um feitor. Porém, exploradores com menos recursos também mandaram escravos para o mesmo serviço. Eram "homens pobres" que

nele [nos serviços de lavra] traziam os seus escravos pela conveniência de se dar ao réu a terça parte do ouro que se tirasse e por alguma equidade que davam ao réu em lhe ajudarem a serrar o cerco do desvio do rio e em recompensa disso lhe deu o réu as duas partes do ouro ficando só com a terça parte. ${ }^{50}$

A maior ou menor eficiência da exploração aurífera não dependia unicamente da técnica empregada ou do capital disponível. As relações estabelecidas entre aqueles que atuavam na exploração do metal também tinham importância fundamental. No caso aqui analisado, o emprego de determinada técnica - a roda d'água para drenagem do local a ser explorado - tem relação com a forma de associação estabelecida, justamente por "exigir" um contingente de mão-de-obra considerável, trazendo para o serviço os escravos de outro grande minerador e de alguns homens pobres. E a eficiência da exploração dependia também do acordo estabelecido entre estes homens e o dono da lavra. Como é sabido, a rede de aliança social e política permeava a economia das minas. Neste sentido, a ajuda periódica ou momentânea de outros senhores ampliava o potencial de trabalho que não se reduzia às próprias posses de escravos do minerador. Essa ajuda se fazia fundamental em muitos casos de lavras de maior envergadura técnica.

Estabelecer relações difusas e costumeiras de associação, por meio de tratos orais, tornou-se um estilo dos trabalhos minerários, envolvendo proprietários, homens livres pobres, faiscadores escravos ou forros. Estes últimos

\footnotetext{
${ }^{49}$ Ibidem.

${ }^{50}$ Ibidem.
} 
sabiam manipular os usos partilhados e a cadeia de direitos, pactuados conforme a tônica do bem comum, notadamente nos assentamentos urbanos. Munidos de poucas ferramentas, os faiscadores aventuravam-se nos locais de exploração comum (nos morros e nas terras consideradas do rocio da vila) ou nas lavras que proporcionavam a partilha de algum rendimento, fossem estas já exploradas ou atulhadas de material que ainda prometiam algum ouro.

\section{Trama dos direitos minerários nos morros das povoações}

Assinalamos que a justiça ordinária ou local não tinha alçada para atuar na administração da mineração do ouro ou arbitrar nos conflitos específicos dos agentes da exploração. Mas, com o povoamento concentrado e a territorialidade da capitania mineira da Coroa, parece evidente que ela passou a desempenhar um papel importante, imiscuindo-se na dinâmica minerária quando julgava temas dos direitos civil ou criminal. De fato, era muito tênue a linha que separava a administração do arbítrio judicial, o que fazia com que as dissensões entre mineradores ou entre associados (ou sócios) muitas vezes chegassem às raias da justiça camarária.

Os guardas-mores da administração das minas não conseguiam arbitrar os conflitos, em muitos casos porque não envolviam somente os concessionários de datas minerais ou porque os agentes traduzissem o objeto da contenda em um tema cível (tabela 3). O recurso dos prejudicados era a defesa dos supostos direitos no âmbito da justiça comum. Em 1767, Domingues Gomes da Fonseca acusou o escravo José Mina e a sua filha Ana (que seria ainda a dona de José) de andarem desfrutando indevidamente dos cercos de mineração deixados pelo falecido Ventura Alves da Costa no morro de Santo Antônio, em Passagem, povoação do termo de Mariana. Ventura Alves fora um preto forro, natural de Angola, e juntara alguns recursos ao longo de sua vida, dedicando-se à exploração do ouro. No seu testamento (1764), constou a posse de uma canoa e de três almocafres, instrumentos utilizados na prática desta atividade. Ventura ainda possuiu quatro escravos e duas moradas de casas situadas na rua de São Gonçalo, na cidade de Mariana. ${ }^{51}$

Ana, defendendo-se da acusação de que não tivesse direito a minerar na lavra do morro, assinalou que possuía "metade de todos os cercos de lavagens que se acham nas vertentes das lavras do capitão Leonel de

\footnotetext{
${ }^{51}$ AHCSM, $1^{\circ}$ ofício, Livro de Registro de Testamentos $n^{\circ}$ 68. Testamento de Ventura Alves da Costa, 1764, f. 87.
} 
Abreu Lima no morro de Santo Antônio". Teria comprado os mesmos cercos e também o embargado José, seu pai, do furriel-mor José de Barros Viana, testamenteiro de Maria Josefa da Conceição, mulher de Ventura. Verifica-se, então, que José fora escravo do liberto Ventura.

Com a morte de Maria Josefa, José de Barros, como seu testamenteiro, vendera os ditos bens a Ana. Porém, Ventura desentendeu-se com o testamenteiro da sua mulher, supondo que este se apropriara de bens que não pertenciam à metade da defunta, mas sim a ele, marido. Para Ventura, José de Barros apossou-se de escravos e de uns brincos e cruz de ouro que custaram uma libra de ouro, sem lhe dar a parte devida. Daí, a disposição testamentária do liberto, visando processar o testamenteiro da sua mulher por causa desta partilha. ${ }^{52}$

Esse enredo está na origem da demanda de Domingues Fonseca. Este entendeu, sendo testamenteiro de Ventura, que Ana não teria direito às benfeitorias da lavra, porque comprara tais bens de José de Barros. Assim, através de uma trama de direitos (escrito, oral) relacionada à partilha dos bens e à legitimidade da posse, chegava-se à alçada da justiça ordinária.

A defesa apresentada pelo procurador de Ana afirmou que os cercos citados na contenda são

todos formados sobre laje com paredes de pedra que não contêm em si outra utilidade mais que as areias que as águas carregam das lavras do capitão Leonel de Abreu Lima; e para aproveitar algum ouro que vem com as ditas areias trabalha a embargante [ré] com seus escravos desviando-lhe as pedras e mexendo as areias de que só poderá ficar algum ouro apurando-o depois em couros [canoa] e sem este trabalho se perdem as referidas areias pelo córrego abaixo. ${ }^{53}$

Foi lembrado ainda que os cercos, sendo construídos na laje (piso de pedra), não poderiam "dar ouro próprio daquele lugar" e que nem Domingues da Fonseca nem Ventura puseram escravos no lugar, fossem próprios ou alugados. Então, de acordo com a defesa dos faiscadores, Domingues não poderia alegar prejuízos, mesmo porque nada o impedia de também ir "mexer" e beneficiar os mesmos cercos, já que Ana era dona apenas da metade dos cercos, a outra metade continuava na posse dos herdeiros do falecido Ventura. De acordo com a ré, ela trabalhava nestes cercos (ou desvios) com sua filha e dois escravos, tirando de jornal no mínimo, por semana, uma oitava de ouro cada pessoa.

\footnotetext{
52 Ibidem.

53 AHCSM, $2^{\circ}$ ofício, Ação cível, Códice 275, Auto 6764, 1767.
} 
Ana beneficiava-se da lama aurífera que vinha das lavras de outra pessoa. Devia se tratar de serviço realizado em terras livres do domínio particular, onde qualquer pessoa podia explorar, tornando-se de uso comum para os faiscadores. O conflito não se estendia à demarcação territorial, mas detinha-se na posse dos cercos estabelecidos em local aparentemente desfavorável aos trabalhos, indicando certa liberdade para entrar na exploração desde que não usufruísse do serviço estabelecido para aproveitar os restos dos desmontes de uma grande lavra que era de Leonel de Abreu Lima, dono de uma "grande fábrica de minerar".

Este minerador, por seu lado, reconhecia os direitos dos faiscadores, declarando que, nas áreas próximas a seus serviços, também havia terras minerais comuns a todos, deixadas à exploração livre do povo. ${ }^{54}$ Mas ele também deve ter se apossado das terras auríferas do morro por meio da constituição de serviços de lavras. ${ }^{55}$

Outro minerador do morro, João Pinto Álvares, testemunhado no caso, confirmou que Ana era "possuidora" da metade dos tais cercos e também do embargado José, seu pai. Tratava-se também de um explorador de muitas posses, que constava na lista dos homens ricos da capitania de Minas Gerais, organizada em 1756 a pedido do Conselho Ultramarino. ${ }^{56}$

Assim como Leonel de Abreu, João Pinto possuía "águas nativas" no morro de Santo Antônio, o recurso essencial para a mineração do lugar. ${ }^{57}$ Estas águas das nascentes dos morros eram frequentemente apropriadas pelos grandes mineradores. Em 1748, quando ficou viúvo, João Pinto possuía 86 escravos trabalhando em sua lavra situada no morro de Passagem. ${ }^{58}$

Os mineradores das lavras das imediações da faisqueira confirmaram as pretensões de Ana. João Pinto observou que "os cercos (...) são formados sobre lajes dos quais se não tira utilidade alguma mais que as areias, e ouro que com elas corre das lavras que se acham pela parte de cima dos ditos cercos". ${ }^{59} \mathrm{O}$ direito costumeiro à faisqueira dos pobres era legítimo, desde que não retirassem rendimentos elevados que obrigassem a uma repartição.

\footnotetext{
${ }^{54}$ AHCSM, $2^{\circ}$ ofício, Livro de Guardamoria 6, 1755, f. 35.

55 AHCSM, $2^{\circ}$ ofício, Ação cível, Códice 275, Auto 6764, 1767.

${ }^{56}$ ALMEIDA, Carla Maria Carvalho de. Ricos e pobres em Minas Gerais: produção e hierarquização social no mundo colonial, 1750-1822. Belo Horizonte: Argvmentvm, 2010, p. 202.

57 AHCSM, $2^{\circ}$ ofício, Livro de Guardamoria 6, 1755, f. 35.

58 AHCSM. $1^{\circ}$ ofício, Códice 46, Auto 1050, 1748. Inventário de Mariana Correa de Oliveira.

59 AHCSM, $2^{\circ}$ ofício, Ação cível, Códice 275, Auto 6764, 1767.
} 
A dinâmica da mineração exposta pelo conflito indica as diferenças entre as explorações dos homens pobres - livres, escravos, libertos - e as dos poderosos senhores de escravos. As relações dos agentes nestes morros das Minas expressavam os ajustamentos conflituosos. Apesar desses embates não oporem necessariamente pobres e poderosos, é certo que estes buscavam enlaçar os outros numa rede de proteção clientelista. Os pobres, afinal, estavam sujeitos a um reconhecimento precário das suas pretensões de posse das faisqueiras, catas ou buracos.

Os direitos dos livres pobres e dos escravos jornaleiros à mineração nos morros eram defendidos pelos grandes mineradores desde que não prejudicassem os seus próprios interesses. Em 1755, Leonel de Abreu Lima, requerendo terras minerais que restaram das explorações de outros no morro de Santo Antônio, observa que a lei ou regimento que declara serem os morros realengos "não é tão absoluta" para não admitir que os mineradores, possuindo águas nativas, tenham a propriedade dessas terras e, assim, possam realizar o serviço de talho aberto. ${ }^{60}$

No entanto, revelando sua tática casuísta, Leonel de Abreu considerou válido o argumento do morro livre para a exploração popular, ou realengo, quando se opôs à necessidade de citar os donos dos serviços abandonados que requeria. Afinal, de acordo com a sua alegação, os serviços eram muito antigos e não seria possível saber quem os havia explorado anteriormente. Argumentava que se devia seguir “a natureza do morro livre e realengo para quem quiser meter mina ou buraco sem dependência de alguma concessão ou licença". 61

Os grandes mineradores, os faiscadores e os exploradores com poucas posses de escravos (condição da proprietária Ana) construíram na lida cotidiana, conforme as situações específicas dos morros, as disposições de convivência que delimitavam os espaços articulados por uns e outros. Os conflitos e as suas resoluções (mesmo que temporárias) serviram para que se construíssem fórmulas usuais da exploração nos morros - o seu estilo de minerar.

Nessas minas, os confrontos enquadrados pela justiça camarária, no entanto, relacionavam-se particularmente às lavras situadas nos ribeiros ou nas suas imediações (tabela 1), talvez porque os mineradores desses lugares, assim como os seus sócios - a quem eram concedidas as mercês das cartas de datas minerárias -, tivessem maior visibilidade jurídica e social, facultando-lhes o recurso, se necessário, ao direito positivo. Por outro lado, 14,2\%

\footnotetext{
${ }^{60}$ AHCSM, $2^{\circ}$ ofício, Livro de Guardamoria 6, 1755, f. 35.

${ }^{61}$ Ibidem, f. 35.
} 
dos conflitos judiciais faziam referência aos serviços realizados nas serras, situados nos altos (grupiaras) e nas encostas dos morros. Especialmente nas serras das proximidades dos núcleos urbanos, distinguindo-se das ocorrências dos vales (ou dos novos descobertos), as apropriações das terras auríferas não costumavam depender das repartições convencionais de datas, mas, sobretudo, dos serviços executados no local, como na trama abordada acima, promovendo uma teia difusa de direitos cuja legitimidade era normalmente arbitrada por agentes experientes da mineração local. Possivelmente, aqui, os constantes litígios sobre os modos de exploração aurífera, se não conduzissem a atitudes criminosas - homicídios, furtos -, buscavam a composição costumeira e oral dos oponentes.

\section{Conclusão}

Os direitos dos agentes da mineração - e dos corpos sociopolíticos envolvidos - condicionaram quaisquer planos de esforço técnico que parecessem eficazes para a extração do ouro. Isso é compreensível quando supomos o enredamento de direitos e privilégios que constituía o exercício dos poderes do Estado, na América portuguesa do século XVIII. Ainda no início do século XIX, o barão Eschwege relatou os obstáculos que enfrentara quando quis explorar uma mina das proximidades da igreja paroquial de Antônio Dias, em Vila Rica, paralisada por causa de duradouro litígio. Aguardando um acordo com os antigos exploradores, o mineralogista resolvera construir uma galeria para chegar até a mina. Quando o serviço já alcançara certa profundidade, "apareceu o curador municipal que embargou o serviço, sob pretexto de que a galeria poderia prejudicar uma barragem próxima e toda a freguesia". Desgostoso, Eschwege desabafou sobre o fracasso do empreendimento: "encontrei contínuos obstáculos e chicanas, cujo inspirador era um funcionário local, ao qual o Governador não teve coragem de opor-se com sua autoridade, porque parecia que aquele tinha a seu favor o direito, oriundo, aliás, de leis absurdas [sic]". ${ }^{62}$

Observa-se nesse relato, conferindo as perspectivas historiográficas, que as águas dos mananciais, no contexto urbano, eram objeto de disputa constante, envolvendo os diversos exploradores, as autoridades municipais ou régias e os outros moradores. Em muitos casos, como o mineralogista in-

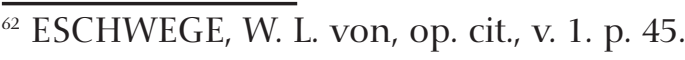


dica, o bem comum dos moradores servia somente de pretexto, encobrindo interesses bem menos virtuosos. De qualquer modo, esses agentes sabiam operar uma cadeia de direitos, estendendo a ambiência litigiosa em demandas que poderiam se arrastar por meio dos embargos e dos recursos judiciais encaminhados às instâncias superiores.

A fluidez dos direitos, porém, contribuiu para que uma gama variada de conflitos fosse resolvida na esfera do costume, ou do estilo das Minas, configurando uma realidade dinâmica de negociações orais e temporárias. É certo que a maior parte das dissensões nas lavras não chegava nem mesmo ao conhecimento do guarda-mor.

As composições orais já se configuravam nas associações entre os agentes da mineração do ouro. Tais sociedades resultavam dos planos exploratórios para compartilhar os fatores de produção - terras, trabalhadores, técnicas -, favorecendo os laços clientelistas ou de amizade entre os envolvidos. Por outro lado, os ajustes corporativos eram sempre temporários, podendo ser rompidos inesperadamente, às vezes com violência, se os participantes não reconhecessem a legitimidade das pretensões. Esses tratos, medidos pelas normas legítimas de estilo, presidiam os processos técnicos.

Portanto, a proposição de uma lógica individualista na extração e na comercialização do ouro constitui uma interpretação claramente anacrônica. Supõe que o minerador ou o mineiro, já antevisto no bandeirante ciumento dos seus descobertos, nunca se disporia, por força de uma ambição desmedida, a dividir os seus interesses, mesmo contrariando a razão produtiva dos trabalhos minerários. O mais importante código das minas, o regimento de 1702, já pressupunha os direitos dos sócios do minerador principal ou do descobridor. Mesmo o senhor de grossa escravaria, dono de data de lavras, fazia composições de serviços com os outros agentes interessados em aproveitar os recursos minerais.

Ao longo do século XVIII, acirrando-se a disputa pelos lugares (e águas) de extração promissora, um negócio de mineração mais lucrativo e menos arriscado dependia dos modos de associação ou de uma sociedade mais orgânica. Tais ajustes disseminaram-se, pois estes convinham às operações técnicas e à manipulação proveitosa dos direitos nas situações específicas das lavras. Por isso, deve-se observar que o contingente de trabalhadores atuantes numa lavra em geral não se reduzia à posse de cativos de um único proprietário, mas incluía os escravos de outros senhores e ainda os homens e as mulheres livres que viviam da faiscação. Neste cenário, quase não havia espaço para o senhor proprietário, agente individual, que pretendesse arcar sozinho com o custeio das atividades extrativas. 
As faisqueiras - comuns ao povo -, notadamente no âmbito urbano, apresentavam formas variadas de ajuste entre os escravos jornaleiros, os forros e os donos de poucos escravos. Elas resultavam, em muitos casos, de uma exploração hábil de terras já lavradas, mas que prometiam um renovado rendimento. As faisqueiras situadas nos morros das vilas das Minas, considerados realengos ou de uso comum dos moradores, garantiam o sustento dos faiscadores que, reunindo-se, concorriam com os serviços dos mineradores. A legitimidade das posses desses lugares dependia dos serviços realizados e não propriamente da demarcação prévia da terra mineral por meio da concessão de datas. Daí o uso costumeiro da denominação de praça, que passou a indicar a ocupação exploradora dos minerais das montanhas.

Depreende-se, enfim, que o exame da dimensão dos investimentos econômicos nas minas da América portuguesa não deve simplesmente basearse no tamanho das propriedades individuais, especialmente de escravos - ou da estrutura de posse de escravos e de terras. É preciso abordar detidamente a tessitura das práticas, com seus agenciamentos específicos e criativos, que compuseram as unidades de extração aurífera.

\section{Referências bibliográficas}

ALMEIDA, Carla Maria Carvalho de. Ricos e pobres em Minas Gerais: produção e hierarquização social no mundo colonial, 1750-1822. Belo Horizonte: Argvmentvm, 2010.

ANASTASIA, Carla Maria Junho. A Lei da Boa Razão e o novo repertório da ação coletiva nas Minas setecentistas. Varia História. Belo Horizonte, n. 28, dez. 2002, p. 37-38.

ANDRADE, Francisco Eduardo de. A administração das minas do ouro e a periferia do poder. In: PAIVA, Eduardo França (org.). Brasil-Portugal: sociedades, culturas e formas de governo no mundo português. São Paulo: Annablume, 2006

ANDRADE, Francisco Eduardo de. A invenção das Minas Gerais: empresas, descobrimentos e entradas nos sertões do ouro da América portuguesa. Belo Horizonte: Autêntica Editora/Editora PUC Minas, 2008.

ANZOATÉGUI, Víctor Tau. El poder de la costumbre. Estudios sobre el Derecho consuetudinario en América hispana hasta la Emancipación. Disponível em:http://www.larramendi. es/i18n/catalogo_imagenes/grupo.cmd?path=1000174. Acesso em 13/02/2011.

BLANCO, Alejandro Vergara. Contribuición a la historia del derecho de águas, III: fuentes y principios del derecho de águas indiano. Revista Chilena de Derecho. Santiago, v. 19, n. 2, 1992, p. 311-332.

BLUTEAU, Rafael. Vocabulario portuguez e latino. Coimbra: Collegio das Artes da Companhia de Jesus, 1712.

CALÓGERAS, João Pandiá. As minas do Brasil e sua legislação. Rio de Janeiro: Imprensa Nacional, 1904.

CHARTIER, Roger. Pierre Bourdieu e a história. Debate com José Sérgio Leite Lopes. In: 
BOURDIEU, Pierre; CHARTIER, Roger. O sociólogo e o historiador. Tradução de Guilherme João de Freitas Teixeira. Belo Horizonte: Autêntica Editora, 2011, p. 87-134.

COUTINHO, José Joaquim da Cunha de Azeredo. Discurso sobre o estado atual das Minas do Brasil [1804]. In: HOLANDA, Sérgio Buarque (org.). Obras econômicas de José Joaquim da Cunha de Azeredo Coutinho. São Paulo: Editora Nacional, 1966.

ESCHWEGE, Wilhelm L. von. Pluto brasiliensis. v. 1. Tradução de Domício de Figueiredo Murta. Belo Horizonte/São Paulo: Itatiaia/ Edusp, 1979.

FERRAND, Paul. O ouro em Minas Gerais. Tradução de Júlio Castanõn Guimarães. Belo Horizonte: Fundação João Pinheiro, 1998.

FERREIRA, Francisco Ignácio. Repertorio juridico do mineiro. Consolidação alphabetica e chronologica. Rio de Janeiro: Typograhia Nacional, 1884.

FIGUEIREDO, Luciano Raposo de Almeida, CAMPOS, Maria Verônica (orgs.). Códice Costa Matoso: coleção das notícias dos primeiros descobrimentos das minas na América que fez o doutor Caetano da Costa Matoso sendo ouvidor-geral das do Ouro Preto, de que tomou posse em fevereiro de 1749, e vários papéis. Belo Horizonte: Fundação João Pinheiro/ Centro de Estudos Históricos e Culturais, 1999.

FONSECA, Alberto de Freitas Castro; PRADO FILHO, José Francisco do. Um importante episódio na história da gestão dos recursos hídricos no Brasil: o controle da Coroa portuguesa sobre o uso da água nas minas de ouro coloniais. Revista Brasileira de Recursos Hídricos, v. 11, n. 3, jul.-set. 2006, p. 5-14.

FONSECA, Cláudia Damasceno. Arraiais e vilas d'el rei: espaço e poder nas Minas setecentistas. Tradução de Cláudia Damasceno Fonseca e Maria Juliana Gambogi Teixeira. Belo Horizonte: Editora UFMG, 2011.

GONÇALVES, Andréa Lisly. Escravidão, herança ibérica e africana e as técnicas de mineração em Minas Gerais no século XVIII. SEMINÁRIO SOBRE ECONOMIA MINEIRA, XI, Diamantina, 2004. Anais eletrônicos. Disponível em: http:// econpapers.repec.org/bookchap/cdpdiam04/. Acesso em 16/05/2011.

HESPANHA, António Manuel. Imbecillitas: as bem aventuranças da inferioridade nas sociedades de Antigo Regime. São Paulo: Annablume, 2010.

HOLANDA, Sérgio Buarque de. A mineração: antecedentes luso-brasileiros. In: Idem. História geral da civilização brasileira. A época colonial. v. 2. $7^{\mathrm{a}}$ edição. Rio de Janeiro: Bertrand Brasil, 1993.

HOLANDA, Sérgio Buarque de. Metais e pedras preciosas. In: Idem. História geral da civilização brasileira. A época colonial. , v. 2. $7^{\mathrm{a}}$ edição. Rio de Janeiro: Bertrand Brasil, 1993.

LATIF, Miran de Barros. As Minas Gerais. 3a edição. Belo Horizonte: Agir, 1960.

LEME, Antonio Pires da Silva Pontes. Memória sobre a utilidade pública em se extrair o ouro das minas e os motivos dos poucos interesses que fazem os particulares, que mineram igualmente no Brasil. Revista do Arquivo Público Mineiro. Ouro Preto, v. 1, n. 3, jul.-set. 1896, p. 417-426.

LUNA, Francisco Vidal. Mineração: métodos extrativos e legislação. Estudos Econômicos. São Paulo, v. 13, número especial, 1983, p. 845-859.

MARCONDES, Renato Leite; COSTA, Iraci del Nero da. "Racionalidade econômica" e escravismo brasileiro: uma nota. Estudos de História. Franca, v. 9, n. 1, 2002. 
MARGADANT, Guillermo F. El agua a la luz del derecho novohispano. Triunfo de realismo y flexibilidad. Anuario Mexicano de Historia del derecho, I. 1989, México: Unam, p. 113-146.

PAIVA, Eduardo França. Bateias, carumbés, tabuleiros: mineração africana e mestiçagem no Novo Mundo. In: ANASTASIA, Carla Maria Junho, PAIVA, Eduardo França (orgs.). O trabalho mestiço, maneiras de pensar e formas de viver - séculos XVI a XIX. São Paulo/Belo Horizonte: Annablume/PPGH-UFMG, 2002, p. 187-207.

PRADO JÚNIOR, Caio. Formação do Brasil contemporâneo. 20a ed. São Paulo: Brasiliense, 1987.

REIS, Flávia M. da Mata. Entre faisqueiras, catas e galerias: explorações do ouro, leis e cotidiano nas Minas do século XVIII (1702-1762). Dissertação de mestrado, História, Faculdade de Filosofia, Letras e Ciências Humanas, Universidade Federal de Minas Gerais, 2007.

RENGER, Friedrich E. Direito mineral e mineração no Códice Costa Matoso (1752). Varia Historia. Belo Horizonte, n. 21, jul. 1999, p. 156-170.

RUGENDAS, Johann Moritz. Imagens e notas do Brasil. Revista do Patrimônio Histórico e Artístico Nacional. Rio de Janeiro, v. 13, 1956, p. 82-83.

RUSSELL-WOOD, Anthony J. R. Technology and society: The impact of gold mining on the institution of slavery in Portuguese America. The Journal of Economic History. Cambridge, v. 37, n. 1, mar. 1977, p. 59-83.

SILVA, Antônio Morais. Diccionario da lingua portugueza. Lisboa: Typographia Lacerdina, 1813.

SILVA, Nuno J. Espinosa Gomes da. História do direito português. Fontes de direito. $4^{\mathrm{a}}$ edição. Lisboa: Fundação Calouste Gulbenkian, 2006.

SIMONSEN, Roberto Cochrane. História econômica do Brasil: 1500-1820. $8^{\mathrm{a}}$ ed. São Paulo: Ed. Nacional, 1978.

TEDESCHI, Denise Maria Ribeiro. Águas urbanas: as formas de apropriação das águas em Mariana/MG (1745-1798). Dissertação de mestrado, História, Instituto de Filosofia e Ciências Humanas/Universidade Estadual de Campinas, 2011.

ZIMMERMANN, Bénédicte; WERNER, Michael. Pensar a história cruzada: entre empiria e reflexividade. Textos de História. Brasília, v. 11, n. 1-2, 2003, p. 89-127.

Recebido: 23/07/2012 - Aprovado: 19/02/2013 